\title{
Proceeding Paper \\ The Use of Apple Pomace in Removing Heavy Metals from Water and Sewage ${ }^{\dagger}$
}

\author{
Kamila Gryko *, Monika Kalinowska (1) and Grzegorz Świderski (1)
}

check for updates

Citation: Gryko, K.; Kalinowska, M.; Świderski, G. The Use of Apple Pomace in Removing Heavy Metals from Water and Sewage. Environ. Sci. Proc. 2021, 9, 24. https://doi.org/ 10.3390 /environsciproc2021009024

Academic Editors: Dorota Anna Krawczyk, Iwona Skoczko, Antonio Rodero Serrano and Ewa Szatyłowicz

Published: 2 November 2021

Publisher's Note: MDPI stays neutral with regard to jurisdictional claims in published maps and institutional affiliations.

Copyright: (c) 2021 by the authors. Licensee MDPI, Basel, Switzerland. This article is an open access article distributed under the terms and conditions of the Creative Commons Attribution (CC BY) license (https:/ / creativecommons.org/licenses/by/ $4.0 /)$.
Department of Chemistry, Biology and Biotechnology, Białystok University of Technology, 15-351 Białystok, Poland; m.kalinowska@pb.edu.pl (M.K.); g.swiderski@pb.edu.pl (G.Ś.)

* Correspondence: k.gryko@pb.edu.pl; Tel.: +48-791-024-055

+ Presented at the Innovations-Sustainability-Modernity-Openness Conference (ISMO'21), Bialystok, Poland, 14 May 2021.

\begin{abstract}
The release of toxic substances in the environment continues to be a problem despite increased efforts to reduce this. The commonly used methods of removing heavy metal ions from water and wastewater have many disadvantages, including a low efficiency and high cost. Heavy metals and dyes are the most problematic pollutants due to their toxicity and stability in the environment. For this reason, in recent years, remediation technologies such as the sorption on materials of natural origin, have been developed. However, these technologies are still rarely used at an industrial level. Recently, scientists have attempted to apply the promising properties of nanotechnology to this field, conducting research on the possibility of using biosorbents in the nanoscale in wastewater treatment. Much attention is currently paid to the preparation of cost-effective, efficient, and environmentally friendly adsorbents, as well as their chemical modifications, to increase the metal removal efficiency from water and wastewater. The waste materials from the agricultural industry are cheap adsorbents that require little treatment. This kind of biosorbent is not able to remove specific metal ions, but by chemical modifications its adsorption capacity and specificity can be increased. The data from the literature are reported for various types of bio-adsorbent materials, e.g., fruit or vegetable pomace and nut shells. One of the most promising raw materials is apple pomace. It was estimated that, in recent years, global apple production reached approximately 75 million tons, equating to 5-7 million tons of apple pomace per year. The management of such waste is a serious challenge. The rational management of exhausting resources requires looking at waste in terms of its use as a reusable raw material. The aim of this paper was to collect information and compare the parameters $(\mathrm{pH}$, dose of adsorbent, and kinetics, etc.) of heavy metal sorption on apple pomace in order to demonstrate the potential of this adsorbent application.
\end{abstract}

Keywords: adsorption; heavy metals; apple pomace; water treatment

\section{Introduction}

One of the most important factors degrading the natural environment are heavy metals of anthropogenic origin. Their presence in surface waters disturbs biological balances, inhibits self-purification processes and makes water treatment processes less effective. A common feature of all the elements, including heavy metals, is that, regardless of their role in the metabolism of plants, animals, or humans, their excess is always harmful. The metals are able to pass easily through biological membranes and form connections with nucleic acids, proteins, and lipids, causing damage to cells and disturbing their metabolic functions. Moreover, some of the metals are carcinogenic [1]. It should be noted that the toxic properties are not displayed by the metals themselves, but by their strongly dissociating and easily soluble compounds. The harmful effect of heavy metals on living organisms is related to their ability to coordinate the functional groups of proteins [2]. Hence, the appropriate approach to heavy metal removal from various discharges is very 
important. There are different methods, but adsorption seems to be the most universal and effective [3]. One notable method is the biosorption process, which uses biological materials to bind pollutants through physico-chemical mechanisms, where factors such as $\mathrm{pH}$, temperature and biosorbent size affect the metal sorption capacity [4]. In this process, substances (heavy metals) are bound on the surface of a biological material. Biosorption mainly refers to the non-living part of the biomass. The use of dead biomass seems to be more advantageous because it does not require the addition of any nutritious substances or the need to conduct the process in sterile conditions.

In the first stage of the biosorption process, the solution containing metal ions contacts with the biosorbent. The ions bind with its functional surface groups. The second stage is desorption, when the metal is released from the biosorbent, followed by the regeneration of the biosorbent. This process allows the multiple use of biomass, as well as recovery of metals from concentrated solutions [2].

In recent years, there has been an increasing trend towards the consumption of plantbased products. This leads to the production of an increasing amount of difficult-to-manage waste, which are fruit and vegetable residues (e.g., seeds and pomace). This waste has the potential to be used as adsorbents of pollutants, including heavy metals from water and sewage [5]. The unused waste from the fruit and vegetable industry creates a risk of environmental contamination. In fruit processing, the main waste is pomace. This constitutes about $20-25 \%$ of the processed raw material. Several hundred thousand tons of pomace is produced every year. It contains significant amounts of celluloses, hemicelluloses and lignins. These ingredients show strong sorption properties to heavy metals [6]. The physicochemical properties of this type of biomass depend on the original source of the pomace [1].

In this paper, the information about heavy metal sorption on apple pomace and its modification was reviewed. The conditions of the sorption process, i.e., $\mathrm{pH}$, the amount of sorbent or the concentration of metal ions, were also taken into account.

\section{Apple Pomace as Biosorbent}

Currently, the waste from apple juice production is often disposed of from the production facility into landfill for natural decomposition. Over time, the waste decomposes in anaerobic processes, which often occur during rainfall and increase environmental pollution, creating an additional source of methane in the atmosphere [7]. Worldwide, up to $19 \%$ of anthropogenic methane comes from landfilled waste, creating a problem for the public and the environment. A reasonable solution seems to be to use valuable waste such as apple pomace, considering their beneficial properties, both for health (they are rich in polyphenols, with proven health-promoting effects) and water treatment (pectins and cellulose contain the functional groups which are responsible for the binding properties of the heavy metal ions) and as a part of a sustainable economy [6,8,9]. Additionally, there is a notable trend of using the chemically modified pomace of apple composites with $\mathrm{MgO}$, hydroxyapatite, or other nanoparticles [10-12].

Based on Table 1, it can be concluded that the unmodified apple pomace was an inefficient sorbent, compared to those subjected to modifications. It is difficult to compare the results obtained by Nawirska and Król [1], because, in this case, more precise sorption parameters, such as the $\mathrm{pH}$ of the amount of sorbent used in the process, are not specified. However, these authors did not obtain a high sorption efficiency. Chand and Pakade [6] optimized the batch sorption process in terms of the $\mathrm{pH}$, sorbent dose and time of the process. On this basis, it was concluded that the best parameters of lead ion sorption at $\mathrm{pH}=4$ were the sorbent dose of $0.8 \mathrm{~g}$ and a process time of $80 \mathrm{~min}$. Designing a composite of apple pomace with hydroxyapatite nanoparticles allowed the same authors to obtain significantly better results [10]. For each of the analyzed metal ions, different process conditions were optimized, with the most preferred $\mathrm{pH}$ of 5 . In the case of lead ions with a concentration of $100 \mathrm{mg} / \mathrm{L}$, the most efficient sorbent dose was $0.02 \mathrm{~g}$; for cadmium in the same concentration, the more efficient amount of sorbent was $0.04 \mathrm{~g}$, and, for nickel ions 
with a concentration of $80 \mathrm{mg}$, $\mathrm{L}-0.06 \mathrm{~g}$ of sorbent was used. Under such conditions, the maximum sorption capacities of 303, 250, and $100 \mathrm{mg} / \mathrm{g}$ were obtained, respectively. In another work, Chand and Bokare [13] used apple pomace modified with methyl acrylate for the sorption of $\mathrm{Pb}(\mathrm{II}), \mathrm{Cd}(\mathrm{II})$ and $\mathrm{Ni}(\mathrm{II})$. However, despite the relatively low concentration of metal ions $(50 \mathrm{mg} / \mathrm{L})$ and high mass of the sorbent $(0.2 \mathrm{~g})$ compared to the methodology with hydroxyapatite nanoparticles, the obtained results did not turn out to be better that the previously described data. Jangde and Umathe [14] used xanthate-modified apple pomace for the fixed-bed sorption of lead ions. In this configuration, a higher maximum sorption capacity for lead ions was obtained, compared to those obtained in the case of unmodified apple pomace during batch sorption [6] but lower than in the case of the apple pomace composite with hydroxyapatite nanoparticles [10].

Table 1. Examples of using apple pomace as biosorbent and optimized sorption details.

\begin{tabular}{|c|c|c|c|c|c|c|}
\hline Sorbent/Sorption Method & Metal & Sorption Parameters & $\begin{array}{c}\text { Maximum } \\
\text { Adsorption } \\
\text { Capacity }\end{array}$ & $\begin{array}{l}\text { Adsorption } \\
\text { Model }\end{array}$ & Kinetic Model & Ref. \\
\hline \multirow{4}{*}{ Apple pomace/batch } & $\mathrm{Zn}(\mathrm{II})$ & $\mathrm{C}=6 \mathrm{mg} / \mathrm{L} \mathrm{Zn}^{2+}$ & $0.12 \mathrm{mg} / \mathrm{g}$ & \multirow{4}{*}{ n.d. } & \multirow{4}{*}{ n.d. } & \multirow{4}{*}{ [1] } \\
\hline & $\mathrm{Cu}(\mathrm{II})$ & $\mathrm{C}=8 \mathrm{mg} / \mathrm{L} \mathrm{Cu}^{2+}$ & $0.27 \mathrm{mg} / \mathrm{g}$ & & & \\
\hline & $\mathrm{Pb}$ (II) & $\mathrm{C}=10 \mathrm{mg} / \mathrm{L} \mathrm{Pb}^{2+}$ & $0.20 \mathrm{mg} / \mathrm{g}$ & & & \\
\hline & $\mathrm{Cd}(\mathrm{II})$ & $\mathrm{C}=4 \mathrm{mg} / \mathrm{L} \mathrm{Cd}^{2+}$ & $0.11 \mathrm{mg} / \mathrm{g}$ & & & \\
\hline \multirow{2}{*}{ Apple pomace/batch } & \multirow{2}{*}{$\mathrm{Pb}(\mathrm{II})$} & \multirow{2}{*}{$\begin{array}{l}0.8 \mathrm{~g} \mathrm{AP} \\
\mathrm{pH}=4 \\
80 \mathrm{~min} \\
\end{array}$} & $16.39 \mathrm{mg} / \mathrm{g}$ & Langmuir & \multirow{2}{*}{$\begin{array}{l}\text { Pseudo-second } \\
\text { order }\end{array}$} & \multirow{2}{*}{ [6] } \\
\hline & & & $16.14 \mathrm{mg} / \mathrm{g}$ & Freundlich & & \\
\hline \multirow[t]{3}{*}{$\begin{array}{l}\text { Hydroxyapatite } \\
\text { nanoparticles impregnated } \\
\text { on apple pomace/batch }\end{array}$} & $\mathrm{Pb}(\mathrm{II})$ & $\begin{array}{l}0.02 \text { g HANP@AP } \\
\mathrm{pH}=5 \\
\mathrm{C}=100 \mathrm{mg} / \mathrm{L} \mathrm{Pb}^{2+} \\
0.04 \mathrm{~g} \text { HANP@AP }\end{array}$ & $303 \mathrm{mg} / \mathrm{g}$ & \multirow[t]{3}{*}{ Langmuir } & \multirow[t]{3}{*}{$\begin{array}{l}\text { Pseudo-second } \\
\text { order }\end{array}$} & \multirow[t]{3}{*}{ [10] } \\
\hline & $\mathrm{Cd}(\mathrm{II})$ & $\mathrm{pH}=5$ & $250 \mathrm{mg} / \mathrm{g}$ & & & \\
\hline & $\mathrm{Ni}(\mathrm{II})$ & $\begin{array}{l}\mathrm{C}=100 \mathrm{mg} / \mathrm{L} \mathrm{Cd}^{2+} \\
0.06 \mathrm{~g} \text { HANP@AP } \\
\mathrm{pH}=5 \\
\mathrm{C}=80 \mathrm{mg} / \mathrm{L} \mathrm{Ni}^{2+}\end{array}$ & $100 \mathrm{mg} / \mathrm{g}$ & & & \\
\hline \multirow{3}{*}{$\begin{array}{l}\text { Methyl acrylate modified } \\
\text { apple pomace/batch }\end{array}$} & $\mathrm{Pb}(\mathrm{II})$ & $\begin{array}{l}0.2 \mathrm{~g} \mathrm{AP} \\
\mathrm{C}=50 \mathrm{mg} / \mathrm{L} \mathrm{Pb}^{2+}\end{array}$ & $106 \mathrm{mg} / \mathrm{g}$ & \multirow{3}{*}{ Langmuir } & \multirow{3}{*}{$\begin{array}{l}\text { Pseudo-second } \\
\text { order }\end{array}$} & \multirow{3}{*}{ [13] } \\
\hline & $\mathrm{Cd}(\mathrm{II})$ & $\begin{array}{l}0.2 \mathrm{~g} \mathrm{AP} \\
\mathrm{C}=50 \mathrm{mg} / \mathrm{L} \mathrm{Cd}^{2+}\end{array}$ & $34.12 \mathrm{mg} / \mathrm{g}$ & & & \\
\hline & $\mathrm{Ni}(\mathrm{II})$ & $\begin{array}{l}0.4 \mathrm{~g} \mathrm{AP} \\
\mathrm{C}=50 \mathrm{mg} / \mathrm{L} \mathrm{Ni}^{2+}\end{array}$ & $19.45 \mathrm{mg} / \mathrm{g}$ & & & \\
\hline $\begin{array}{l}\text { Xanthate-modified apple } \\
\text { pomace/fixed-bed column }\end{array}$ & $\mathrm{Pb}(\mathrm{II})$ & $\begin{array}{l}\mathrm{C}=30 \mathrm{mg} / \mathrm{L} \mathrm{Pb}^{2+} \\
\mathrm{C}=40 \mathrm{mg} / \mathrm{L} \mathrm{Pb}^{2+} \\
\mathrm{C}=50 \mathrm{mg} / \mathrm{L} \mathrm{Pb}^{2+}\end{array}$ & $\begin{array}{l}160 \mathrm{mg} / \mathrm{g} \\
165 \mathrm{mg} / \mathrm{g} \\
177 \mathrm{mg} / \mathrm{g}\end{array}$ & Thomas & Second-order & [14] \\
\hline
\end{tabular}

\section{Conclusions}

Taking into account the results obtained by the researchers, it can be concluded that apple pomace may be a promising sorption material for removing metal ions from wastewater. Moreover, chemical modifications may significantly increase the sorption capacity of biosorbents. In this regard, the nano-modification seems to be a promising modification for heavy metal ions removal.

Author Contributions: K.G. writing; M.K. concept and editing; G.Ś. editing. All authors have read and agreed to the published version of the manuscript.

Institutional Review Board Statement: Not applicable.

Informed Consent Statement: Not applicable.

Data Availability Statement: The data presented in this study are available on request form the corresponding author. 
Acknowledgments: This research was carried out as part of the work no. WI/WB-IIŚ/4/2021 and financed from funds for the education of the Ministry of Science and Higher Education.

Conflicts of Interest: The authors declare no conflict of interest.

\section{References}

1. Król, S.; Nawirska, A. Usuwanie jonów metali ciężkich na wytłokach owocowych w układach dynamicznych. Technol. Aliment. 2003, 2, 21-29.

2. Dudczak, J.; Kalak, T.; Cierpiszewski, R. Usuwanie jonów $\mathrm{Cu}(\mathrm{II})$ z roztworów wodnych przy pomocy wytłoków z czarnego bzu. In Zagospodarowanie Ubocznych Produktów Przemystu Spożywczego; Wydział Nauk o Żywności i Żywieniu, Uniwersytet Przyrodniczy w Poznaniu: Poznań, Poland, 2016; pp. 57-64.

3. Zolfaghari, G.; Esmaili-Sari, A.; Anbia, M.; Younesi, H.; Amirmahmoodi, S.; Ghafari-Nazari, A. Taguchi optimization approach for $\mathrm{Pb}(\mathrm{II})$ and $\mathrm{Hg}(\mathrm{II})$ removal from aqueous solutions using modified mesoporous carbon. J. Hazard. Mater. 2011, 192, 1046-1055. [CrossRef] [PubMed]

4. Saikaew, W.; Kaewsarn, P. Pomelo Peel: Agricultural Waste for Biosorption of Cadmium Ions from Aqueous Solutions. World Acad. Sci. Eng. Technol. 2009, 56, 287-291.

5. Torres, E. Biosorption: A review of the latest advances. Processes 2020, 8, 1584. [CrossRef]

6. Chand, P.; Pakade, Y.B. Removal of $\mathrm{Pb}$ from water by adsorption on apple pomace: Equilibrium, kinetics, and thermodynamics studies. J. Chem. 2013, 1, 1-8. [CrossRef]

7. Yatim, N.I.; Ariffin, M.M.; Hamzah, S. Removal of heavy metals using self-integrating bio-adsorbent from agricultural by-products and marine waste materials. Desalin. Water Treat. 2018, 118, 216-229. [CrossRef]

8. Bhushan, S.; Kalia, K.; Sharma, M.; Singh, B.; Ahuja, P.S. Processing of apple pomace for bioactive molecules. Crit. Rev. Biotechnol. 2008, 28, 285-296. [CrossRef] [PubMed]

9. Godlewska-Żyłkiewicz, B.; Świsłocka, R.; Kalinowska, M.; Golonko, A.; Świderski, G.; Arciszewska, Ż.; Nalewajko-Sieliwoniuk, E.; Naumowicz, M.; Lewandowski, W. Biologically active compounds of plants: Structure-related antioxidant, microbiological and cytotoxic activity of selected carboxylic acids. Materials 2020, 13, 4454. [CrossRef] [PubMed]

10. Chand, P.; Pakade, Y.B. Synthesis and characterization of hydroxyapatite nanoparticles impregnated on apple pomace to enhanced adsorption of $\mathrm{Pb}(\mathrm{II}), \mathrm{Cd}(\mathrm{II})$, and $\mathrm{Ni}(\mathrm{II})$ ions from aqueous solution. Environ. Sci. Pollut. Res. 2015, 22, 10919-10929. [CrossRef] [PubMed]

11. Dakroury, G.A.; Abo-Zahra, S.F.; Hassan, H.S. Utilization of olive pomace in nano $\mathrm{MgO}$ modification for sorption of Ni(II) and $\mathrm{Cu}(\mathrm{II})$ metal ions from aqueous solutions. Arab. J. Chem. 2020, 13, 6510-6522. [CrossRef]

12. Mahamadi, C. Will nano-biosorbents break the Achilles' heel of biosorption technology? Environ. Chem. Lett. 2019, 17. [CrossRef]

13. Chand, P.; Bokare, M.; Pakade, Y.B. Methyl acrylate modified apple pomace as promising adsorbent for the removal of divalent metal ion from industrial wastewater. Environ. Sci. Pollut. Res. 2017, 24, 10454-10465. [CrossRef] [PubMed]

14. Jangde, V.; Umathe, P.; Antony, P.S.; Shinde, V.; Pakade, Y. Fixed-bed column dynamics of xanthate-modified apple pomace for removal of $\mathrm{Pb}(\mathrm{II})$. Int. J. Environ. Sci. Technol. 2019, 16, 6347-6356. [CrossRef] 